\title{
マイクロ波照射による実大模型の気化式加湿器エレメントの温度分布 空調用気化式加湿器のマイクロ波殺菌に関する研究（その 2 ) \\ AN EXPERIMENTAL STUDY ON THE TEMPERATURE DISTRIBUTION OF EVAPORATIVE HUMIDIFIER ELEMENTS IRRADIATED BY MICROWAVE
}

Germicidal effect of microwave radiation on microbial contamination of evaporative humidifier in HAVC system Part 2

\author{
姜 允 敬*, 加藤信 介**, 成 旻 起***, 柳 宇**** \\ 阿部恵子 $* * * *$, 原田光朗 $* * * * *$
Yoonkyung KANG, Shinsuke KATO, Minki SUNG, U YANAGI, Keiko ABE and Mitsuo HARADA

In this study, microwave irradiation was considered to be used to sterilize evaporative humidifiers in air-conditioning systems. A mockup of humidifier was prepared to identify the applicability of the microwave irradiation system. For effective heating of an evaporative humidifier element, the optimum operating conditions of the system such as usage of air blower and water spray during microwave irradiation, microwave output powers and dry or wet element condition were investigated. The results showed that the front surface temperature of the element was higher in wet condition than in dry condition, whereas back surface temperature was higher in dry condition. Further study to make the surface temperature of the element uniformly high shall be necessary.

Keywords: Microwave irradiation, germicidal effect, evaporative humidifier, temperature distribution マイクロ波, 殺菌, 気化式加湿器、温度分布

1. はじめに

加湿器は室内の湿度調節のみならず、加湿によって湿度を上昇させ ることで、低湿度時に発生しやすい呼吸系疾患の予防機能も兼社備え ている。気化式加湿器は水滴中に存在する無機成分の残留成分による 微粒子をエアロゾル化させない特徴を有しており、また、エレメント がフィルターのように空気中の浮遊污染物質を除去する機能も持つ。 しかし、気化式加湿器は加湿水の高い清浄度が確保されたにも関わら ず、エレメント表面での微生物による污染の可能性が指摘されている 1-2)。また、気化式加湿器エレメントの表面での微生物污染が深刻にな るとその污染物質が室内に放散する可能性もある ${ }^{3)}$ 。そのため、気化 式加湿器において微生物污染を防ぐことは重要な課題となっている ${ }^{4)}$ 一つの方策としてマイクロ波による殺菌が考えられる。筆者らは既報 5)において、真菌胞子 (Cladosporium herbarum、Fusarium solani ) 及び細菌（Bacillus subtilis）を対象菌としてマイクロ波による殺菌 が可能であることを確認した。また、その殺菌原理を明らかにするた

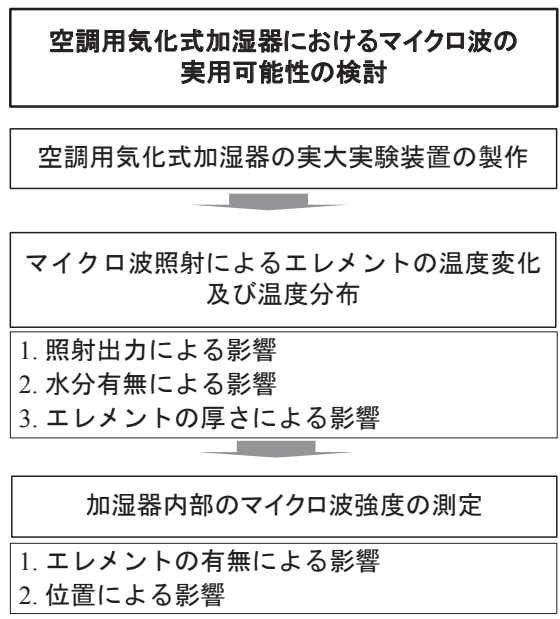

図 1 実験概要

\footnotetext{
* 東京大学大学院工学系研究科 大学院生 · 修士 (理学)

Graduate Student, the University of Tokyo, M. Sci.

** 東京大学生産技術研究所 教授. 工博

*** 東京大学 特任研究員.工博

$* * *$ 工学院大学 教授. 工博

$* * * * *$ 環境生物学研究所 所長. 農博

****** 東京電力法人営業部産業 $\mathrm{ES}$ 部 スペシャリスト

Prof., Institute of Industrial Science, the University of Tokyo, Dr. Eng.

Project Researcher, Institute of Industrial Science, the University of Tokyo, Dr. Eng.

Prof., Kogakuin University, Dr. Eng.

Institute of Environmental Biology, Dr. Agr.

Tokyo Electric Power Company
} 
めにマイクロ波の殺菌効果及び同温度条件でマイク 口波を用いない非マイク口波の殺菌効果を比較する 基礎検討結果を報告した。その結果、マイクロ波の殺 菌は熱による効果であることを明らかにしたと共に、 菌液（ $0.9 \%$ 食塩水）の温度が約 $60^{\circ} \mathrm{C}$ 以上の条件で殺 菌効果が高いことを報告した。

本報では空調用気化式加湿器におけるマイクロ波 の実用性を検討するために加湿器の模型実験装置を 製作し、加湿器エレメントの温度がマイクロ波照射に より殺菌効果が高かった温度である約 $60^{\circ} \mathrm{C}$ 以上にな る条件を検討する。まず、実験による検討の際、安全 管理上、空調機からのマイクロ波の漏れを防ぐのが実 用化一の重要な前提条件となるため、併せてマイクロ 波の模型実験装置からの漏れについて検討する。その 後、殺菌条件を検討寸るために行った加湿器一の給水 と送風機の稼働有無、マイクロ波の出力、エレメント 上の水分の有無によるエレメント表面の温度変化及 び温度分布の測定結果を報告する（図 1 ）。

\section{2. 空調用気化式加湿器の模型実験装置の製作及び マイクロ波漏れの確認}

\section{1 空調用気化式加湿器の模型実験装置の製作}

空調用気化式加湿器の全体の模型実験装置を図 2 に 示す。模型実験装置は HEPA フィルター付き給排気 口及び排気送風機、マイクロ波発生装置、ダクト、気 化式加湿器で構成されている。排気送風機を稼働する とき気流は図 2 のように吸入口から出口に向かって流 れてくる。サンプリング空は加湿器エレメントにおけ る試験菌付着の有無などを確認するために設けた。気 化式加湿器は給水ポンプ、積算流量計、水槽、加湿器 エレメントから構成される(図 3)。マイクロ波発生装 置は周波数 $2455 \mathrm{MHz} \pm 30 \mathrm{MHz}$ であり、最大出力 は $2000 \mathrm{~W}$ である。加湿器エレメントはハニカム構造 であり、無機充填材と無機結合材で構成された不燃タイプである。

\section{2 マイクロ波漏れの確認}

加湿器上部の気密性の確保及びマイクロ波漏れを防止するため、部 材内部の隙間には導電性ゴムを、外部の隙間には導電性テープを付け た。また、加湿器とダクトの連結部及びシールド部には導電性テープ を付けた。実験装置周辺のマイクロ波強度を高周波電磁界測定器 （TES-92、TES Electrical Electronic 社）を用いて測定した結果、 公共の場所における ICNIRP（国際非電磁波放射線防護委員会）6)基 準 $10 \mathrm{~W} / \mathrm{m}^{2}$ の 1/10 以下であることが確認された。

\section{3. マイクロ波照射によるエレメント表面の温度変化及び温度分布}

既報ではマイクロ波による殺菌効果は主に熱によるものであり、真 菌胞子及び細菌に対して約 $60^{\circ} \mathrm{C}$ 以上の温度条件において殺菌効果が 認められることについて報告した。本報では効率的に加湿器エレメン 卜を加熱するために加湿器への給水及び送風機の稼働有無、マイクロ 波の出力、水分の有無によるエレメント表面の温度変化及び温度分布 について詳細な検討を行った。

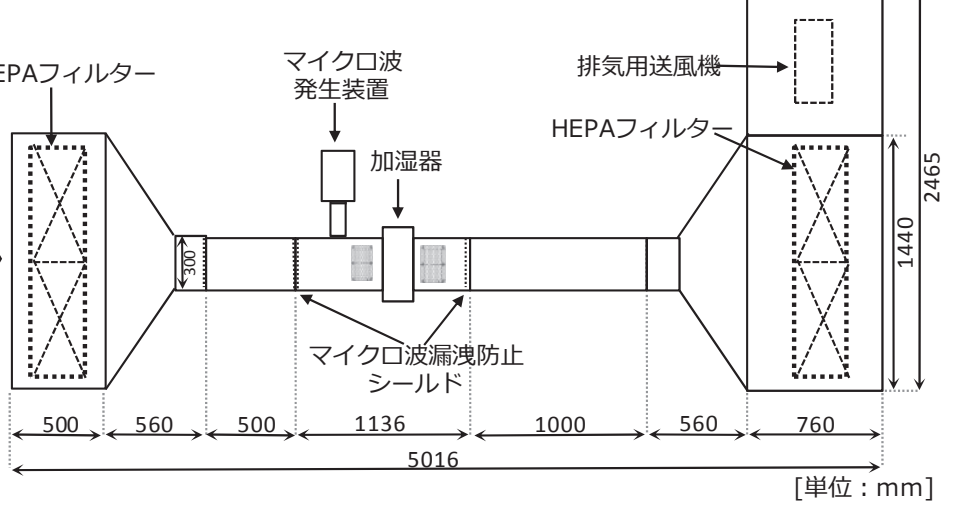

図 2 模型実験装置

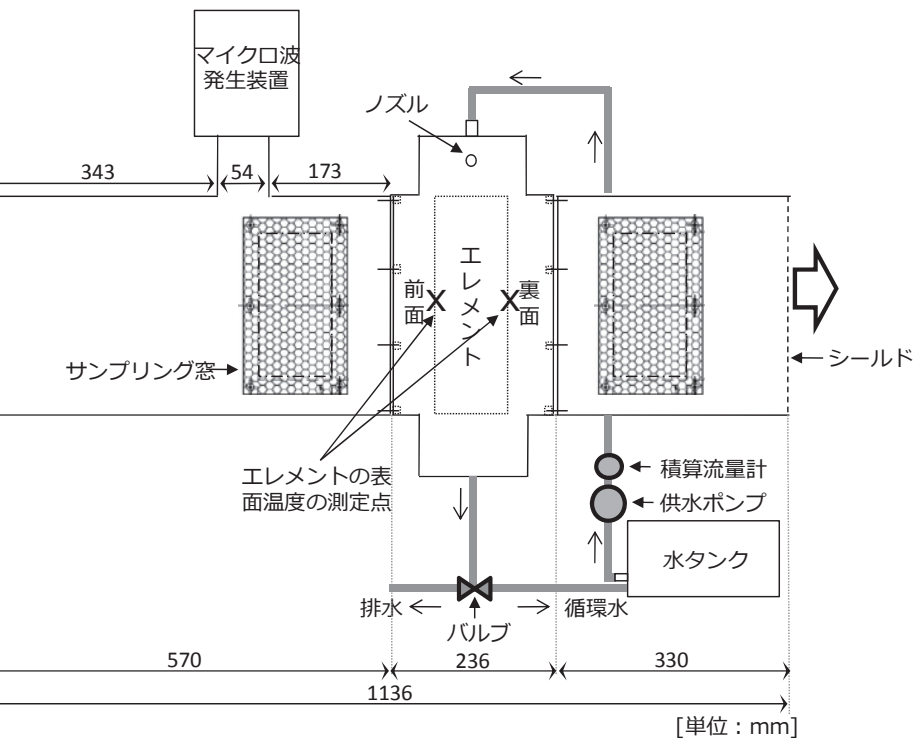

図 3 空調用気化式加湿器の模型実験装置

\section{1 実験方法}

3.1.1 加湿器への給水と送風機の稼働有無によるエレメント表面の 温度変化

マイクロ波による加熱はエネルギー消費量、安全、殺菌効果などを 考慮したスケジュールを決めて断続的に行う必要があり、空調機の運 転スケジュールによって加湿器及び送風機が稼働しない場合がある ため、空調機の運転可否がマイクロ波加熱に与える影響及びそれによ るエレメント表面の温度変化を確認するための試験を行った。

加湿器と送風機を稼働する場合は、加湿器エレメントに給水すると 共に送風機を稼働させ、水を十分エレメントに染み込ませてから、エ レメント表面の温度が $60^{\circ} \mathrm{C}$ 以上に上昇するまで $1200 \mathrm{~W}$ のマクロ 波を照射する。送風量は $29.1 \mathrm{~m}^{3} / \mathrm{min}$ であり、気化式加湿器の給水流 量は $0.48 \sim 0.52 \mathrm{~L} / \mathrm{min}$ である。加湿器と送風機を稼働しない場合に は、加湿器エレメントへの給水と送風機の稼働を行い、エレメントを 十分に水で湿らせて加湿器の給水と送風機の稼働を停止する。エレメ ントから水が落ちなくなるまで待った後、エレメントが濡れている状 態で $1200 \mathrm{~W}$ のマクロ波を照射する。エレメント表面の温度測定は 光ファイバー温度センサー $\left(\right.$ Reflex $^{\mathrm{TM}}, \mathrm{Neoptix}$ 社) を用いてエレメン 
トの前面及び裹面中央の表面温度を測定する（図 4-(a))。そこで前面 と裏面はマイクロ波を照射する上流側のエレメント面を前面、下流側 のエレメント面を裏面とする (図 3)。エレメントは厚さ $100 \mathrm{~mm}$ の 1 枚条件で行う。

\subsection{2 マイクロ波の出カによるエレメント表面の温度変化}

マイクロ波照射による加湿器エレメントの表面温度が殺菌に有効 な温度である $60^{\circ} \mathrm{C}$ 以上になる条件を検討寸るためにマイクロ波の出 力によるエレメント表面の温度変化を測定する。マイクロ波の出力を $450 \mathrm{~W} 、 600 \mathrm{~W} 、 750 \mathrm{~W} 、 900 \mathrm{~W} 、 1050 \mathrm{~W} 、 1200 \mathrm{~W} 、 1350 \mathrm{~W}$ の 7 段階に設定し、エレメント表面の温度が十分に上昇し安定するまでマ イクロ波を照射する。加湿器と送風機は稼働しない条件、エレメント は乾燥させた条件及び 1 枚のみを設置した条件で行う。エレメントの 温度測定はエレメントの前面及び裏面中央の表面温度を測定する。

\subsection{3 水分有無によるエレメント表面の温度変化及び温度分布}

3.1.2の実験では乾燥したエレメントにマイクロ波を照射するが、 実際の加湿器エレメントは、その使用時には常に水で濡れている状態 である。従って、エレメントが濡れている状態でマイクロ波を照射し、 水の蒸発によるエレメントの乾燥の過程を含めた温度の時間推移を 検討寸る必要がある。そこで、加湿器エレメントが濡れている状態及 び濡れていない状態でマイクロ波を照射した際のエレメント表面の 温度変化を確認する。

加湿器エレメントが濡れていない場合（乾燥条件）は、エレメント が乾燥している状態で $1200 \mathrm{~W}$ のマイクロ波を照射する。加湿器エレ メントが水で濡れている場合（非乾燥条件）には、加湿器を稼働させ エレメントに給水する。そしてエレメントから水が落ちなくなるまで 約 5 分間待った後、マイクロ波を照射しエレメントの表面温度を測定 する。加湿器と送風機は稼働させず、エレメントは乾燥条件及び 1 枚 のみを設置した条件で行う。また、加湿器部とダクト部を分離し、赤 外線カメラ (Fluke Ti25, FLUKE 社) を用いてエレメントの前面と 裏面の温度分布を測定する（図 4-(b))。

\subsection{4 エレメントの枚数による温度変化及び温度分布}

エレメントが厚い場合、内部まで殺菌が可能であるかを検討するた め、厚さ $100 \mathrm{~mm}$ のエレメント 1 枚と 2 枚の 2 ケースに対して $1200 \mathrm{~W}$ のマイクロ波を照射し温度変化を比較する。エレメント表面の温度変 化はエレメントの前面、前面と裏面の間、及び裏面の中央を測定する (図 5)。また、エレメントの前面と裏面の温度分布を測定する。加湿 器と送風機は稼働しない条件、エレメントは乾燥条件で行う。

\section{2 実験結果}

3.2.1 加湿器への給水と送風機の稼働有無によるエレメント表面の 温度変化

加湿器と送風機を稼働させながらマイクロ波を照射した場合、温度 変化が殆ど見られなかった（図 6-(a))。一方、加湿器と送風機を稼働 させない場合、エレメント前面及び裏面の温度は約 $55 \sim 60^{\circ} \mathrm{C}$ まで上 昇した（図 6-(b))。加湿器と送風機を稼働させた場合、エレメントの 温度変化が殆ど見られなかった理由としては、加湿のために供給した 水と送風の影響によりエレメント表面の温度上昇が抑制されたため と考えられる。前報で確認したように、対象とする微生物を殺菌する ためにはエレメントの表面温度を約 $60^{\circ} \mathrm{C}$ 以上に上げる必要がある。 そのため、以後の実験では加湿器と送風機を稼働させない条件でマイ クロ波を照射することにした。

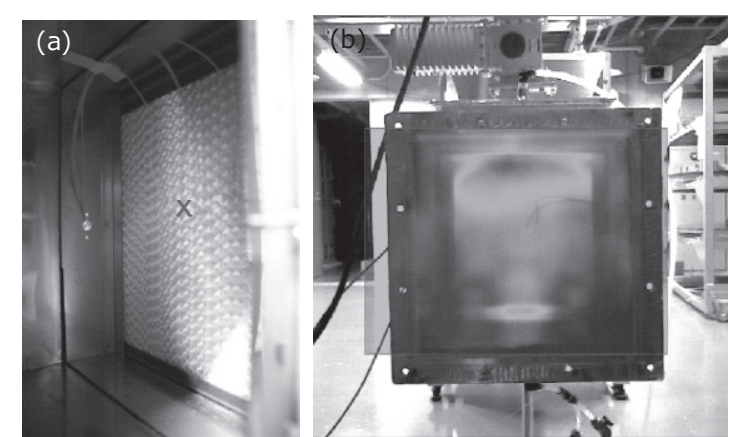

図 4 気化式エレメントの表面温度測定

(a) 温度センサー設置（光ファイバー温度計）

(b) 温度分布測定（赤外線カメラ） (a)

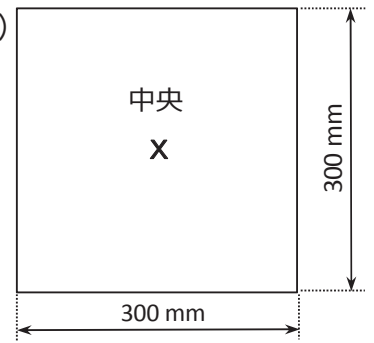

(b)

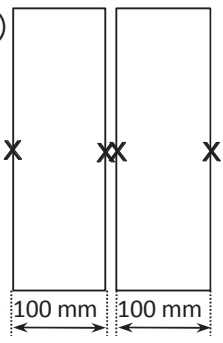

図 5 気化式エレメントの表面温度測定点

(a) 前面 (b) 側面
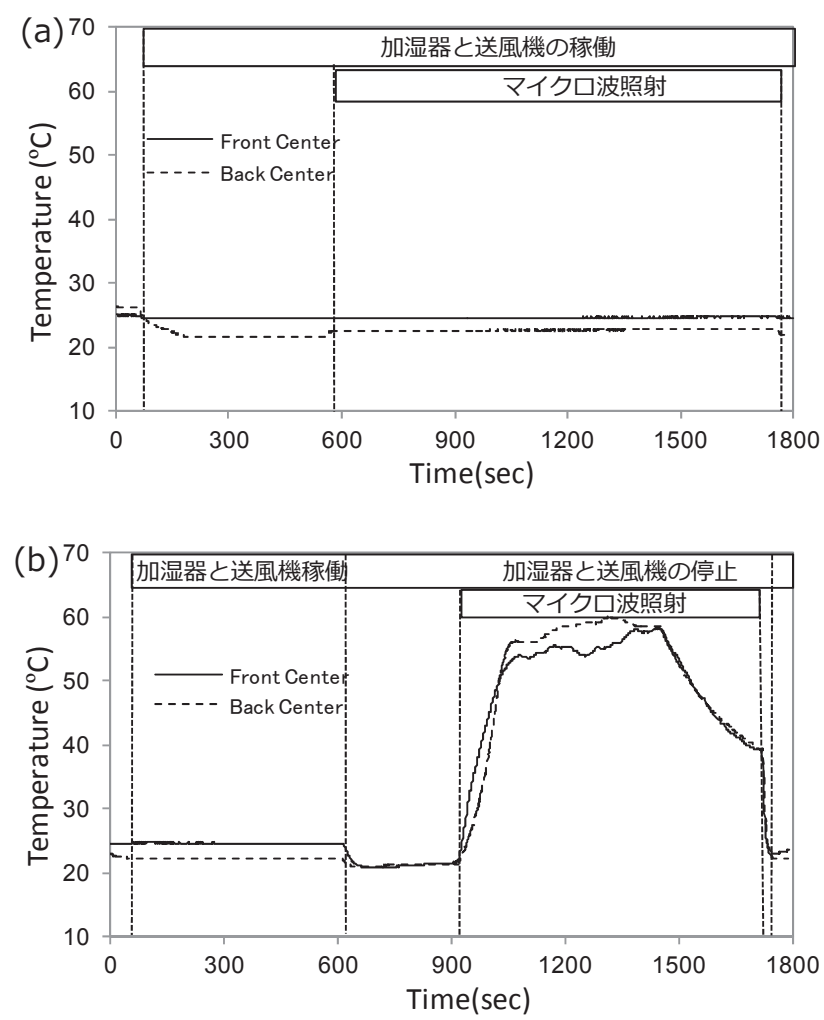

図 6 加湿器と送風機の稼働有無によるエレメント表面の温度変化 （a）加湿器と送風機の稼働（b）加湿器と送風機の未稼働 


\subsection{2 マイクロ波の出カによるエレメント表面の温度変化}

マイクロ波の出力によるエレメント表面の温度変化を測定した結 果を図 7 に示す。マイクロ波の出力によってエレメント表面の温度が が上昇した。また、エレメントの裏面温度は前面温度より多少低かっ た。 $1200 \mathrm{~W}$ の出力でマイクロ波を照射した場合、エレメントの前面 温度は照射 3 分後に約 $60^{\circ} \mathrm{C}$ まで上昇した。

\subsection{3 水分の有無によるエレメント表面の温度変化及び温度分布}

水分の有無によるエレメント表面の温度変化及び温度分布を測定 した結果を図 8、9 に示す。乾燥条件において $1200 \mathrm{~W}$ の出力でマイ クロ波を照射してから 2 分後にエレメント前面の温度の方が裏面に比 ベ少し高めであるが、続けてマイクロ波を照射したら 6 分後にはエレ メント前面と裏面の温度差が殆なくなった（図 8-(a))。また、エレメ ント表面の温度分布は全体的に温度むらが生じて中心部の温度が低 く、それ以外の温度は高い傾向を示す（図 8-(b), (c))。また、前面（図 8-(b)）と裏面（図 8-(c)）の温度分布は同じ傾向を示す。この結果から マイクロ波はエレメント前面を通過しており、エレメント内部にまで 十分到達し加熱していると考えられる。

非乾燥条件では、エレメント前面と裏面の温度差が大きく(図 9-(a)) 前面（図 9-(b)）と裏面（図 9-(c)）の温度分布は異なる。これはマイ
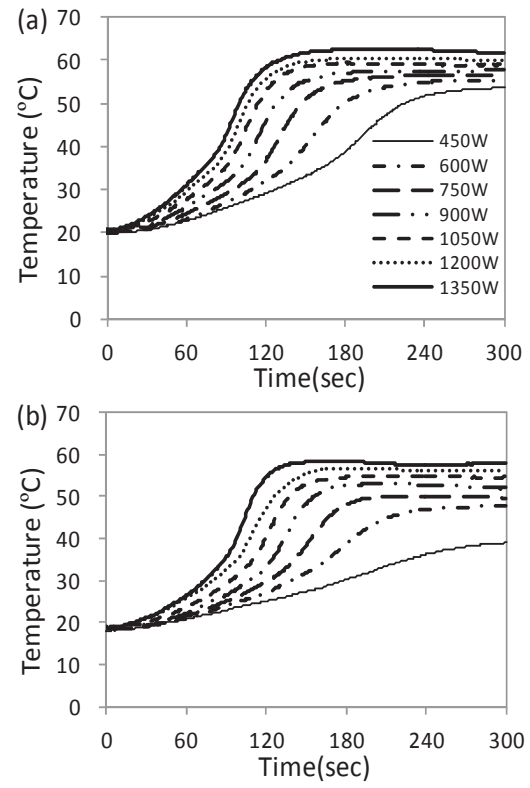

図７ママイクロ波出力によるエレメント表面の温度変化 (a) 前面 (b) 裏面
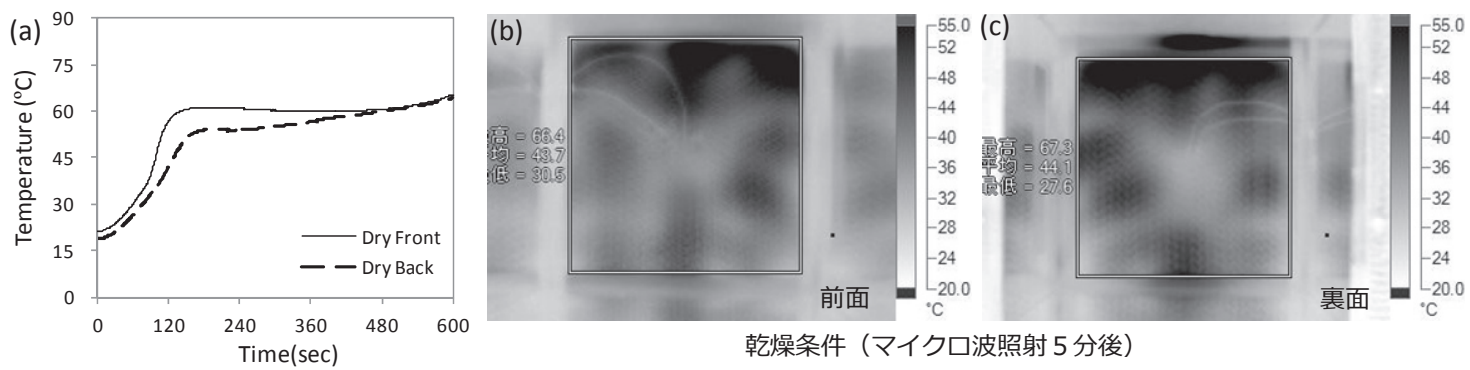

図 8 乾燥条件でのエレメント温度変化の比較

(a) 温度変化

(b) 前面の温度分布

(c) 裏面の温度分布
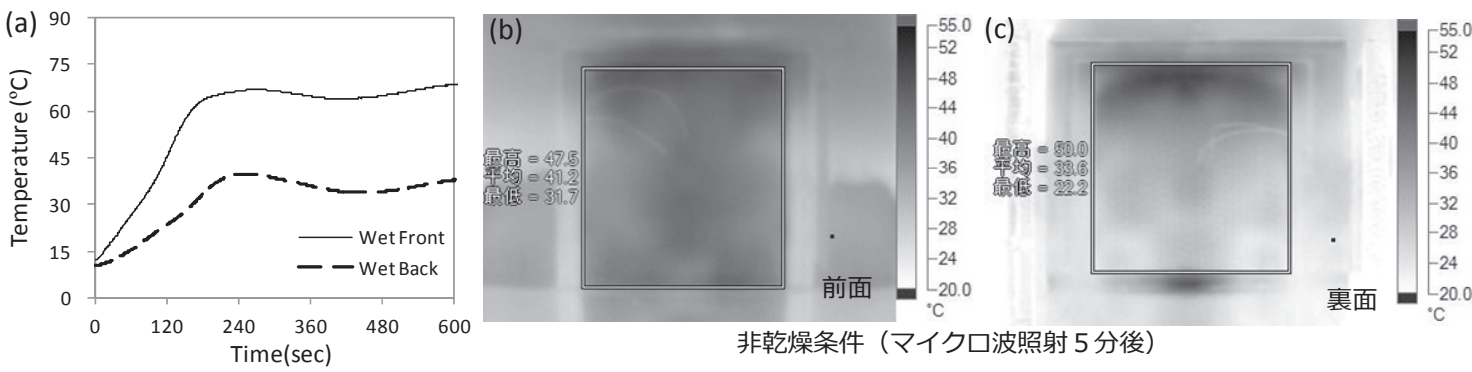

図 9 非乾燥条件でのエレメント温度変化の比較

(a) 温度変化

(b) 前面の温度分布

(c) 裏面の温度分布
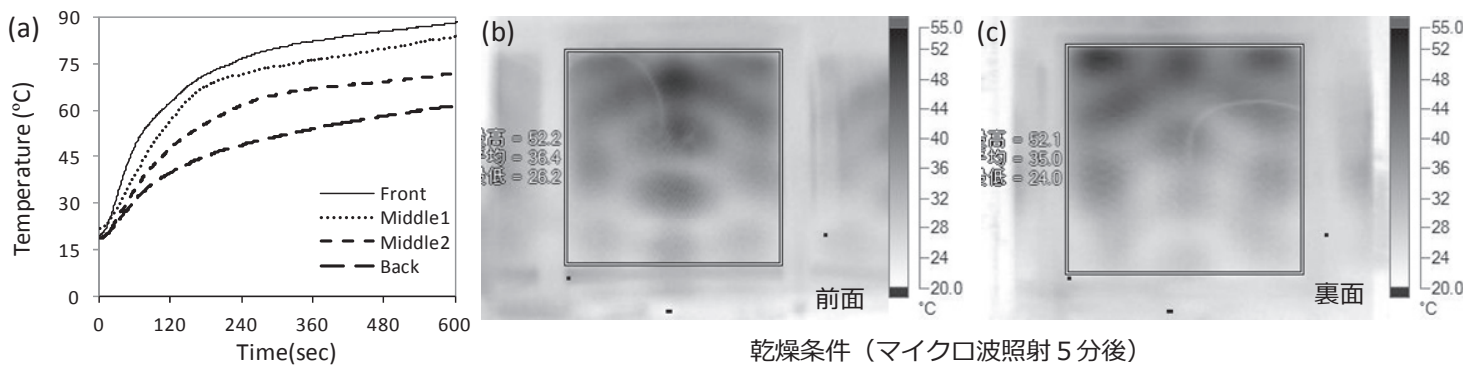

乾燥条件（マイク口波照射 5 分後）

図 10 エレメント（乾燥条件）２枚条件でのエレメント温度変化の比較

(a) 温度変化

(b) 前面の温度分布

(c) 裏面の温度分布 
クロ波がエレメント前面の水分に優先的に吸収されるため、裏面温度 が前面温度より低くなったことが原因であると考えられる。その結果 から水分の有無はマイクロ波加熱の効果に対して重要な因子である と判断される。

\subsection{4 エレメントの枚数による温度変化及び温度分布}

エレメント枚数によるエレメント表面の温度変化及び温度分布を 測定した結果を図 10 に示す。全体的に 0 ～600 分までの平均裏面温度 はエレメント 1 枚（図 8-(a)）より 2 枚（図 10-(a)）の方が多少低か った。また、エレメント 2 枚の場合も前面(図 10-(b)) と裏面(図 10-(c)) の温度分布は一致する。その結果からマイクロ波はエレメント 2 枚で も通過すると考えられる。また、エレメント 2 枚（図 10-(b)，(c)）の 温度分布はエレメント 1 枚（図 8-(b), (c)) の温度分布と異なる。この 結果からエレメントが 1 枚ある場合と 2 枚ある場合は加湿器内部のマ イクロ波分布が異なると考えられる。なお、エレメントの裏面は殺菌 可能なエレメント表面の温度とした約 $60^{\circ} \mathrm{C}$ よりも高い $61.4^{\circ} \mathrm{C}$ であり、 エレメントが厚い場合も十分にマイクロ波を照射すると裏面まで加 熱可能であると判断される。

\section{4. 加湿器模型装置内部のマイクロ波強度の測定}

先の章ではマイクロ波照射によりエレメントに温度むらが生じる ことが確認された。本章では原因を確かめるために、(1) マイクロ波 を照射する位置からの距離とマイクロ波強度の関係、(2) 加湿器の形 とマイクロ波強度の関係、(3) エレメントに吸収されるマイクロ波強 度を考慮して行われた。加湿器内部におけるマイクロ波強度分布の測 定とその結果について示す。

\section{1 実験方法}

各実験のケースはエレメントがない場合（Case1）及びエレメント が 1 枚ある場合（Case2）、エレメントが 2 枚ある場合（Case 3$)$ を検 討寸る。すべてのケースはエレメントを乾燥した条件、送風機及び加 湿器を稼働してない条件で行う。

測定方法を以下に示す。 $50 \mathrm{~mL}$ の蒸留水を入れた $100 \mathrm{~mL}$ 容量のガ ラスビーカーをエレメントの前後に配置し、1200 W のマイクロ波を 1 分間照射する。

測定点は図 11 のように(1)から（8)とする。エレメントに吸収される マイクロ波の強度を確認するためにエレメントに接触している測定 点（3）、(4)、(5)、(6)）とエレメントに接触していない測定点（11、（2)、 (7)、(8)）のマイクロ波強度を比較する。また、ダクトの形が対称なの でマイクロ波強度も対称であることが想定される。それを確認するた めにダクトの中心（図 11 の点線）に関して対称な位置に測定点を設 けた。一回の計測でエレメントに接触していない測定点とエレメント に接触している測定点で 2 回に分けて行った。水の温度の測定は光つ アイバー温度センサーを用いて行う。

筆者らは一分間の照射の間に上昇する蒸留水の温度を指標として式
（1）によりマイクロ波強度を算定した。水の温度は照射初期には上 昇するが、やがて周辺空気との熱バランスにより温度の時間勾配が小 さくなり平衡状態に近づいてゆく。本研究では空気温度を計測してお らず、水から空気への熱輸送を定量評価できない。従って本報告では 試験方法は JIS C 92507) 参考とし照射初期の水の温度上昇率をもつ てマイクロ波強度を大まかに算定することを試みた。

\section{2 実験結果}

\subsection{1 マイクロ波を照射する位置からの距離とマイクロ波強度の関係}

蒸留水の温度及び計算したマイクロ波の強度を表 1 に示す。マイク 口波を照射する位置から近い測定点（位置(1)，(2)）から遠い測定点（位 置(7)，(8)）のマイクロ波強度の測定結果、エレメントがない場合 (Case1)、マイクロ波を照射する位置からの距離とマイクロ波強度に 一定の傾向は見られず加湿器内部の位置により異なるマイクロ波強 度を示した。
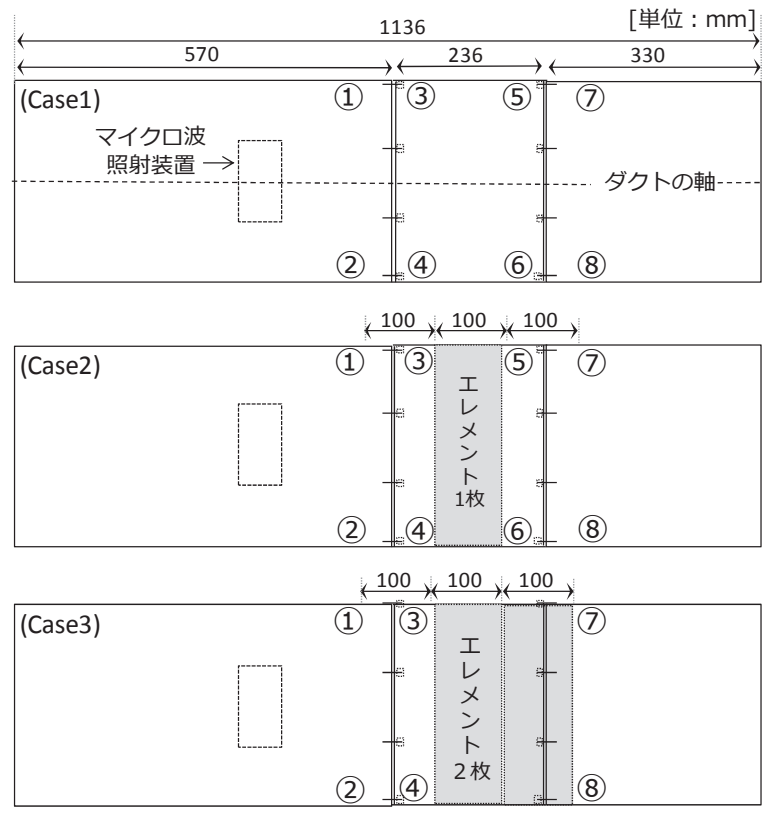

図 11 加湿器内部のマイクロ波強度の測定位置 (平面図) Case1 : エレメントなし, Case2 : エレメント 1枚, Case3 : エレメント 2 枚 (1)から8はマイクロ波強度の測定位置を示す。

\begin{tabular}{|c|c|}
\hline $\mathrm{W}=\mathrm{M} \times \mathrm{C} \times\left(\mathrm{T}_{\mathrm{b}}-\mathrm{T}_{\mathrm{a}}\right) / \mathrm{t}$ & 式（1） \\
\hline W ：マイクロ波強度 & {$[\mathrm{W}]$} \\
\hline M ：蒸留水質量 & {$[\mathrm{g}]$} \\
\hline $\mathrm{C}$ ：蒸留水の比熱 & {$\left[\mathrm{J} / \mathrm{g} \cdot{ }^{\circ} \mathrm{C}\right]$} \\
\hline $\mathrm{T}_{\mathrm{a}}$ ：マイクロ波照射前の蒸留水温度 & {$\left[{ }^{\circ} \mathrm{C}\right]$} \\
\hline $\mathrm{T}_{\mathrm{b}}$ ：マイクロ波照射後の蒸留水温度 & {$\left[{ }^{\circ} \mathrm{C}\right]$} \\
\hline t ：マイクロ波照射時間 & {$[\mathrm{sec}]$} \\
\hline
\end{tabular}

表 1 加湿器内部のマイクロ波強度

\begin{tabular}{|c|c|c|c|c|c|c|c|c|c|}
\hline \multirow{2}{*}{ エレメント } & \multirow{2}{*}{ ケース } & \multicolumn{8}{|c|}{ マイクロ波強度（W） } \\
\hline & & (1) & (2) & (3) & (4) & (5) & (6) & (7) & (8) \\
\hline なし & Case1 & 76 & 53 & 118 & 131 & 60 & 64 & 175 & 147 \\
\hline 1 枚 & Case2 & 153 & 161 & 75 & 61 & 58 & 40 & 124 & 133 \\
\hline 2 枚 & Case3 & 98 & 93 & 96 & 78 & - & - & 43 & 41 \\
\hline
\end{tabular}




\subsection{2 加湿器の形とマイクロ波強度の関係}

全体的に図 11 におけるダクトの軸を示寸点線に関して対称な各測 定点（11-(2)、(3)-(4)、(5)-(6)、(7)-(8) でマイクロ波強度がほぼ同じ傾向 を示した。その結果から加湿器の形は加湿器内のマイクロ波強度に大 きな影響を与えると考えられる。また、ダクトの軸方向に (1)-(3)-(5)(7)方向）関しては加湿器内部のマイクロ波強度にばらつきが出た。こ れは加湿器内部に定在波が生じている可能性が考えられる。

\subsection{3 エレメントに吸収されるマイクロ波強度}

エレメントに接触している測定点とエレメントに接触していない測 定点のマイクロ波強度を比較した結果、エレメントが 1 枚ある場合 (Case2)、エレメントに接触する測定点（位置(3), (4), (5), (6) ) よりエ レメントから $10 \mathrm{~cm}$ 離れた測定点（位置(1), (2), (7), 8) のマイクロ波 強度が強かった。しかし、エレメント 2 枚がある場合（Case3）には、 エレメントに接触する測定点（位置(3)，(4)）とエレメントから $10 \mathrm{~cm}$ 離れた測定点（位置(1)，(2)）のマイクロ波強度の差はほぼなかった。 その結果からエレメントに吸収されるマイクロ波強度は予測が困難 であると考えられる。

\section{5. 考察}

前報では、マイクロ波の殺菌は主に熱の影響であり、約 $60^{\circ} \mathrm{C}$ 以上 の温度条件で殺菌効果が見られたことを確認した。これを踏まえて本 研究ではマイクロ波の実用性を検討するために加湿器の模型実験装 置を製作し、加湿器エレメントを約 $60^{\circ} \mathrm{C}$ 以上に加熱する方法を検討 した。その結果、乾燥したエレメント 1 枚を設置した場合、加湿器へ の給水と送風機を稼働させない条件で $1200 \mathrm{~W}$ の出力のマイクロ波を 2 分以上照射すると、エレメントの表面温度が $60^{\circ} \mathrm{C}$ まで上昇するこ とが確認された。また、濡れているエレメント1枚を設置した場合は $1200 \mathrm{~W}$ の出力のマイクロ波を 3 分以上照射すると $60^{\circ} \mathrm{C}$ まで上昇した。

また、乾燥したエレメント 2 枚を設置した場合は $1200 \mathrm{~W}$ の出力の マイクロ波を 10 分以上照射するとエレメント裏面の表面温度が $60^{\circ} \mathrm{C}$ まで上昇した。濡れているエレメントを 2 枚設置する場合に関しては 実験を行わなかったが、以上の結果から、適切な時間マイクロ波を照 射することによりエレメントが前面から乾燥し、最終的には乾燥した エレメント 2 枚を設置した場合と同様に、裏面まで加熱が可能である と考えられる。

紫外線による気化式加湿器エレメントの殺菌はエレメント表面の 殺菌には有効であるが、紫外線が届かないエレメント内部までは殺菌 効果が期待できないと報告されている ${ }^{8)}$ 。その一方でマイクロ波によ る加湿器エレメントの殺菌は以上の実験からエレメント内部まで殺 菌が可能であると判断される。

しかし、エレメント表面に不均一な温度むらが生じ、エレメント温 度が $60^{\circ} \mathrm{C}$ より低いところが生じる可能性があるため、エレメント全 体で均一な殺菌は期待されないと考えられる。また、温度むらの形は エレメントが乾燥条件にある場合と濡れている条件にある場合で異 なる。エレメントの水分有無は温度むらの形に大きな影響が与えると 考えられる。

エレメントに生じる温度むらの原因を確認するために加湿器内部 のマイクロ波分布を確認した結果、加湿器内部の軸対称な各測定点で マイクロ波強度がほぼ同じ傾向を示したが、ダクトの軸方向に関して は加湿器内部の位置により異なるマイクロ波強度を示した。これはマ
イクロ波強度が空間分布を持っているということであり、定在波が加 湿器内部に生じている可能性があることを示している。強度測定点を 加湿器床面近傍の夕に設置し、加湿器内部の鉛直方向のマイクロ波強 度は本実験では計測しなかったため、鉛直方向の強度分布については 言及できない。しかしエレメント表面で生じる鉛直方向の温度むらに 関しても、定在波によるものである可能性はある。そして水分の有無 やエレメント枚数が、マイクロ波の定在波形に影響するために各設定 条件でのエレメント温度分布が異なったという可能性が考えられる。

したがって定在波の存在を実証し、それを適切に制御・調整し温度 むらが生じない照射方法を開発する必要があると考えられる。その方 法として、今後はマイクロ波シミュレーションを用いて実験を再現し、 エレメントへの均一な加熱が可能になるように反射板等を設けるな どの対策を検討する予定である。

\section{6. まとめ}

本研究ではマイクロ波の実用性を検討するために加湿器の模型実 験装置を製作し、マイクロ波照射の出力、水分有無によるエレメント 表面の温度変化と温度分布を確認した。また、加湿器内部のマイクロ 波強度分布を確認した。本研究で得られた結果を以下に示す。

（1）加湿器と送風機を稼働させた場合は、加湿器エレメントの表面 温度上昇が殆どなかった。

（2）乾燥条件のエレメントに関して加湿器と送風機を稼働しない条 件で $1200 \mathrm{~W}$ の出力のマイクロ波を 2 分以上照射した場合、エレメン 卜前面の表面温度は約 $60^{\circ} \mathrm{C}$ まで上昇した。また、エレメント表面に 不均一な温度むらが生じた。

（3）エレメント前面温度は乾燥条件に比べ非乾燥条件の方が高かっ た。非乾燥条件の場合、エレメント前面温度と裏面温度の差が大きか った。また、乾燥条件のエレメントの温度むらと異なる形の温度むら が生じた。

（4）加湿器内部の位置によりマイクロ波強度が異なる。それにより エレメントに温度むらが生じたと考えられる。

\section{参考文献}

1) Harriet A. Burge, William R. Solomon, and Jean R. Boise, Microbial prevalence in domestic humidifiers, Applied and Environmental Microbiology, 39(4), pp. 840-844, 1980.

2) Eva Henningson, Emission of bacteria from air humidifiers, Environment International, 17, pp. 235-241, 1991.

3）山嵪省二、木村昌伸、竹下節、Jan Wettergard : 加湿器から空中への細菌飛 散の機序に関する研究、第 9 回空気清浄とコンタミネーションコントロール 研究大会予稿集, pp. 83-86, 1990.

4）池田耕一, 仲井章一, 田村和也, 気化式加湿より発生する菌および臭気等の 対策に関する実験的研究: 運用上効果のある方法の選定に関する検討, 空気調 和・衛生工学会大会学術講演論文集, F-13, pp. 477-480, 2011. 9 .

5）姜 允敬, 加藤 信介, 成 旻起, 金 鐘訓, 柳 宇, 阿部 恵子, 原田 光朗, 柳原 隆司, 空調用気化式加湿器のマイクロ波殺菌に関する研究 (その 1) マイクロ 波による微生物殺菌性能に関する基礎実験、日本建築学会環境系論文集 第 667 号, pp.793-798, 2011.9.

6) ICNIRP Guidelines, Guidelines for limiting exposure to time-varying electric, magnetic, and electromagnetic fields, International Commission on Non-Ionizing Radiation Protection, 74 (4) , pp. 494-522, 1998.

7) JIS C 9250 Microwave ovens, 1992.

8) Minki Sung, Shinsuke Kato, U Yanagi, Minsik Kim and Mitsuo Harada, Disinfection performance of ultraviolet germicidal irradiation systems for the microbial contamination on an evaporative humidifier, HVAC\&R 17(1), pp. 22-30, 2011 